\title{
Penerapan Model Discovery Learning Terhadap Motivasi Dan Hasil Belajar Siswa Pada Materi Besaran Dan Satuan MTs Muslimat NU Palangka Raya
}

\author{
Jasmin*, Suhartono, Muhammad Nasir \\ ${ }^{1)}$ Program Studi Tadris Fisika, Jurusan Pendidikan Matematika dan Ilmu Pengetahuan Alam, Fakultas \\ Tarbiyah dan Ilmu Keguruan, Institut Agama Islam Negeri Palangka Raya, Palangka Raya, \\ Kalimantan Tengah. \\ Email: jasminmarewo153@gmail.com
}

\begin{abstract}
Abstrak
Penelitian ini bertujuan untuk mengetahui perbedaan motivasi belajar siswa sebelum dan sesudah penerapan model discovery learning pada materi besaran dan satuan. Penelitian ini menggunakan pendekatan penelitian kuantitatif pra eksperimental dengan desain One Group Pretest-Posttest design. Pengambilan sampel menggunakan pupossive sampling, sampel yang dipilih yaitu kelas VII. Penelitian ini dilaksanakan di MTs Muslimat NU Palangka Raya. Instrumen yang digunakan adalah tes hasil belajar, dan lembar angket motivasi belajar siswa. Hasil penelitian menunjukkan terdapat perbedaan yang signifikan motivasi belajar siswa sebelum dan setelah penerapan model discovery learning dengan taraf signifikansi $0,000<0,05$. Berdasarkan hasil dan pembahasan dapat disimpulkan bahwa terdapat perbedaan yang signifikan motivasi dan hasil belajar siswa MTs Muslimat NU Palangka Raya sebelum dan sesudah penerapan model pembelajaran discovery learning pada materi besaran dan satuan dengan tingkat ketuntasan sebesar $63,64 \%$ dalam kategori sedang.
\end{abstract}

Kata Kunci: Discovery learning, hasil belajar, motivasi, besaran dan satuan

\section{Abstract}

This study aims to determine the differences in student learning motivation before and after the application of discovery learning models in the material quantities and units. This study used a preexperimental quantitative research approach with One Group Pretest-Posttest design. Sampling using purposive sampling, the sample selected is class VII. This research was conducted at MTs Muslimat NU Palangka Raya. The instrument used was a test of learning outcomes and student motivation questionnaire sheets. The results showed that there were significant differences in student learning motivation before and after the application of the discovery learning model with a significance level of $0.000<0.05$. Based on the results and discussion, it can be concluded that there are significant differences in the motivation and learning outcomes of students at MTs Muslimat NU Palangka Raya before and after the application of the discovery learning model to the material of magnitude and unit with a completeness level of $63.64 \%$ in the medium category.

Keywords: discovery learning model. Learning motivation, studen's learning outcome

\section{PENDAHULUAN}

Kualitas pendidikan meliputi berbagai sektor dan jenjang pendidikan, termasuk jenjang pendidikan menengah pertama. Keberhasilan suatu pendidikan dipengaruhi oleh berbagai faktor termasuk guru. Guru harus berupaya menciptakan strategi belajar yang cocok dalam upaya meningkatkan proses belajar mengajar. Guru juga harus mampu menciptakan suasana pengajaran yang menarik bagi siswa. Agar siswa tidak cepat bosan terhadap suatu pelajaran yang diberikan dan 


\section{JPSP: Jurnal Penelitian Sains dan Pendidikan}

\section{https://e-journal.iain-palangkaraya.ac.id/index.php/mipa/}

mampu menumbuhkan motivasi belajar serta meningkatkan konsentrasi belajar siswa.

Mewujudkan hal tersebut guru dituntut untuk mampu mengelola dan menguasai kelas dengan baik termasuk memiliki strategi pembelajaran yang sesuai dengan materi dan tujuan pembelajaran, sehingga siswa lebih aktif dalam suatu proses pembelajaran. Dalam konteks ini siswa bertugas untuk belajar mencari, menemukan, menyimpulkan sendiri sebagai nilai-nilai pengamalan, pengetahuan yang dibutuhkan yaitu memecahkan masalah, dan menerapkan apa yang dipelajari.

Berdasarkan hasil observasi awal pada kelas VII di MTs Muslimat NU Palangka Raya ditemukan beberapa permasalahan antara lain; kurangnya antusiasme motivasi dan kerjasama dari siswa apabila dibentuk sebuah kelompok. Siswa cenderung mengandalkan penjelasan dari guru dan tidak mau berusaha mencari tahu terlebih dahulu mengenai materi yang akan dipelajari. Sebagian siswa menganggap bahwa pelajaran IPA khususnya fisika merupakan pelajaran yang sulit dan membosankan. Sehingga siswa kurang termotivasi untuk sekedar belajar kembali materi yang telah diajarkan.

Berdasarkan hasil wawancara dengan guru mata pelajaran IPA Terpadu menyebutkan bahwa model pembelajaran yang diterapkan di sekolah adalah model pembelajaran DI (Direct Instruction), sehingga siswa hanya bergantung kepada guru pada saat proses pembelajaran berlangsung. Siswa cenderung pasif dan hanya menghapal rumusrumus fisika.
Permasalahan ini dikuatkan dengan hasil angket motivasi belajar yang diberikan kepada siswa dengan presentase rata-rata yang diperoleh adalah sebesar 44,16\% dari enam indikator motivasi belajar, hasil presentase tersebut menunjukkan bahwa pembelajaran yang diterapkan di kelas tersebut masih kurang mampu meningkatkan motivasi belajar siswanya.

Salah satu cara untuk mengatasi permasalahan yang dikemukakan di atas yaitu dengan menerapkan model discovery learning. Model discovery learning merupakan model pembelajaran yang memberikan kesempatan pada siswa untuk terlibat lebih aktif dalam proses pembelajaran berusaha mencari dan menemukan secara mandiri mengenai permasalahan yang mereka hadapi dalam proses pembelajaran. Menurut Hadiono \& Hidayati (2016) bahwa penerapan model discovery learning dapat meningkatkan motivasi dan hasil belajar siswa serta cocok untuk diterapkan dalam proses pembelajaran.

Discovery learning merupakan model pembelajaran yang digunakan untuk memecahkan masalah sendiri oleh siswa secara intensif dibawah arahan guru yang mengawasi proses pembelajaran berlangsung. Pada model discovery learning guru membimbing siswa untuk memecahkan dan menjawab masalah yang ada. Discovery learning merupakan model pembelajaran kognitif yang menuntut guru lebih kreatif untuk menciptakan situasi pembelajaran untuk siswa lebih aktif dalam proses pembelajaran untuk memecahkan masalah dan menemukan pengetahuan sendiri. Bruner dalam Dahar 


\section{JPSP: Jurnal Penelitian Sains dan Pendidikan}

\section{https://e-journal.iain-palangkaraya.ac.id/index.php/mipa/}

(2006) menyarankan agar siswa belajar melalui keterlibatannya secara aktif dengan konsepkonsep dan prinsip yang dapat menambah pengalaman dan mengarah pada kegiatan eksperimen.

Berdasarkan hasil penelitian di atas dapat disimpulkan bahwa pembelajaran dengan menggunakan model discovery learning dapat diterapkan untuk meningkatkan motivasi belajar siswa yang pada akhirnya akan meningkatkan hasil belajar siswa.

Motivasi merupakan faktor dari dalam diri siswa yang mempengaruhi keinginannya untuk melakukan proses pembelajaran. Motivasi sangat berperan penting dalam proses pembelajaran untuk mencapai suatu keberhasilan proses belajar siswa. Karena setiap siswa pasti memiliki keinginan untuk mencapai suatu tujuan tertentu dalam belajar. Motivasi sebagai penggerak untuk mencapai tujuan tersebut. Apabila motivasi tersebut tidak ada dalam diri siswa secara tidak langsung proses pembelajaran tidak akan berlangsung secara maksimal dan hasilnya pun menjadi lemah.

Berdasarkan latar belakang, maka tujuan yang dikemukakan dalam penelitian ini adalah (1) mengetahui perbedaan motivasi belajar siswa sebelum dan sesudah penerapan model discovery learning pada materi besaran dan satuan kelas VII-A MTs Muslimat NU Palangka Raya tahun pelajaran 2018-2019; (2) mengetahui perbedaan hasil belajar siswa sebelum dan sesudah penerapan model discovery learning pada materi besaran dan satuan kelas VII-A MTs Muslimat NU Palangka Raya tahun pelajaran 2018-2019.

\section{METODE PENELITIAN}

Populasi dalam penelitian ini adalah seluruh kelas VII MTs Muslimat NU Palangka Raya. Dalam pengambilan sampel menggunakan teknik purpossive sampling yaitu teknik sampling yang digunakan oleh peneliti jika peneliti mempunyai pertimbangan- pertimbangan tertentu di dalam pengambilan sampelnya Arikunto (2006). Peneliti menentukan kelas VII-A MTs Muslimat NU Palangka Raya untuk sampel penelitian. Penelitian ini dilakukan pada tahun ajaran 2018-2019.

Penelitian ini menggunakan pendekatan penelitian kuantitatif. Jenisi penelitian ini adalah penelitian praeksperimental dengan desain One Group Pretest-Posttest design. Penelitian ini membandingkan motivasi dan hasil belajar kognitif siswa MTs Muslimat NU Palangka Raya kelas VII-A sebelum dan sesudah penerapan model discovery learning pada materi besaran dan satuan.

Penelitian ini menggunakan teknik pengumpulan data yaitu dengan metode angket untuk mengukur motivasi belajar siswa serta metode tes untung mengukur hasil belajar kognitif siswa. Instrumen pengambilan data menggunakan tes. Adapun mekanismenya sebelum digunakan dalam penelitian ini, instrument penelitian terlebih dahulu dilakukan analisis mengenai validasi, reliabilitas, tingkat kesukaran dan daya pembeda.

Untuk mengetahui perbedaan hasil belajar kognitif siswa peneliti menganalisis dengan menggunakan $n$-gain yaitu 


$$
g=\frac{X_{\text {postest }}-X_{\text {pretest }}}{X_{\text {max }}-X_{\text {pretest }}}
$$

\section{HASIL DAN PEMBAHASAN}

Hasil belajar adalah adanya perubahan tingkah laku pada siswa, misalnya dari tidak tahu menjadi tahu, dan dari tidak mengerti menjadi mengerti Hamalik (2006). Hasil belajar adalah kemampuan-kemampuan yang dimiliki siswa setelah ia menerima pengalaman belajarnya. Kemampuankemampuan itu akan membawa perubahan dalam diri siswa baik berupa membentuk pola pikir baik, tingkah laku, pengetahuan, pamahaman dan juga semangat belajar yang tinggi dimiliki oleh siswa.

Hasil perbeadaan motivasi belajar siswa kelas VII-A MTs Muslimat NU Palangka Raya setelah penerapan model discovery learning pada materi beasran dan satuan yaitu

\section{Perbedaan Hasil Motivasi Belajar Siswa}

Sebelum dan Sesudah Penerapan Model

\section{Discovery Learning}

Hasil angket motivasi belajar siswa setelah penerapan model discovery learning ditunjukan melalui grafik perbandingan nilai rata-rata pretest, posttest, gain dan $\mathrm{N}$-gain hasil angket motivasi belajar sebagai berikut:

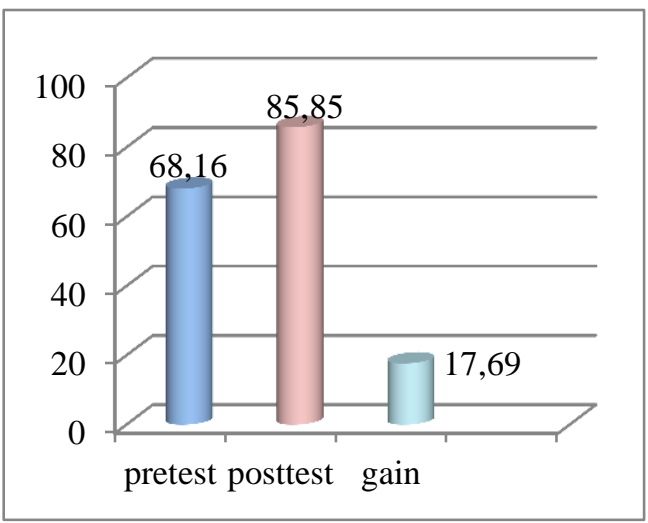

Gambar 1. hasil angket motivasi belajar siswa setelah penerapan model discovery learning

Grafik $1 \mathrm{~N}$-Gain hasil angket motivasi belajar siswa setelah penerapan model discovery learning

Persentase perbedaan motivasi belajar siswa setelah penerapan model discovery learning diperoleh 0.19. Hal ini menunjukkan bahwa terdapat perbedaan motivasi belajar siswa dengan menggunakan model discovery learning pada materi besaran dan satuan yang terlihat pada grafik 1. Model discovery learning memiliki kelebihan diantaranya: (1). Siswa lebih antusiasme dan semangat dalam proses pembelajaran; (2). Siswa lebih aktif dan memiliki kemauan yang tinggu untuk berusaha mencari tahu dan menemukan sendiri konsep dalam pembelajaran; (3). Siswa memiliki tingkat daya ingat yang tinggi karna pada pembelajaran menggunakan model discovery learning siswa berperan aktif dalam menemukan dan memecahkan sendiri permasalahan yang dihadapinya.

Roestiyah (2012) menyatakan bahwa manfaat dari model discovery learning bagi siswa adalah "Tumbuh rasa percaya diri pada siswa karena telah menemukan konsep baru dengan proses penemuan, meningkatkan semangat belajar siswa, melalui semangat belajar siswa akan tumbuh minat belajar sehingga motivasi belajar siswa menjadi lebih besar". Hal ini menyebabkan dengan penerapan model discovery learning motivasi belajar siswa dapat meningkat dengan signifikan. 


\section{JPSP: Jurnal Penelitian Sains dan Pendidikan}

\section{https://e-journal.iain-palangkaraya.ac.id/index.php/mipa/}

Model Discovery learning merupakan model pembelajaran penemuan bukan hanya menuntut siswa untuk menguasai materi pelajaran, tetapi juga dituntut untuk menggunakan segenap potensi yang dimilikinya Dahar (2006). Model Discovery learning memiliki kelebihan antara lain: Discovery learning pembelajaran yang melibatkan siswa dalam proses kegiatan mental melalui tukar pendapat, diskusi, membaca dan mencoba sendiri agar siswa dapat belajar sendiri Roestiyah (2008). Model discovery learning mempunyai kelebihan yakni tumbuhnya rasa percaya diri pada siswa, dapat meningkatkan semangat belajar siswa sehingga dapat meningkatkan motivasi belajar siswa., siswa dapat mengembangkan, memperbanyak kesiapan serta penguasaan keterampilan dalam proses kognitif. Selain itu juga dalam model discovery learning siswa menemukan konsepnya dengan mandiri sehingga konsep tersebut dapat dipahami bukan dihafal dalam ingatan bersifat sementara

Adapun yang menjadi faktor penghambat kurang maksimalnya pengkatan motivasi belajar siswa MTs Muslimat NU Palangka Raya pada penerapan model discovery learning pada materi besaran dan satuan adalah siswa belum terbiasa dengan model pembelajaran yang menutut siswa berperan aktif untuk menemukan dan memecahkan sendiri permasalahan yang dihadapinya. Selain itu juga jumlah siswa yang terlalu banyak dalam kelas juga menjadi faktor penyebab lainnya. Di samping itu juga derdapat sebagian siswa yang pasif dan enggan mau berusaha mencoba menemukan dan memecahkan sendiri permasalahan yang dihadapinya.

\section{Perbedaan Hasil Belajar Kognitif Siswa}

Sebelum dan Sesudah Penerapan Model

\section{Discovery Learning}

Hasil belajar kognitif siswa setelah penerapan model discovery learning ditunjukan melalui grafik perbandingan nilai rata-rata pretest, posttest, gain dan $\mathrm{N}$-gain hasil belajar kognitif sebagai berikut:

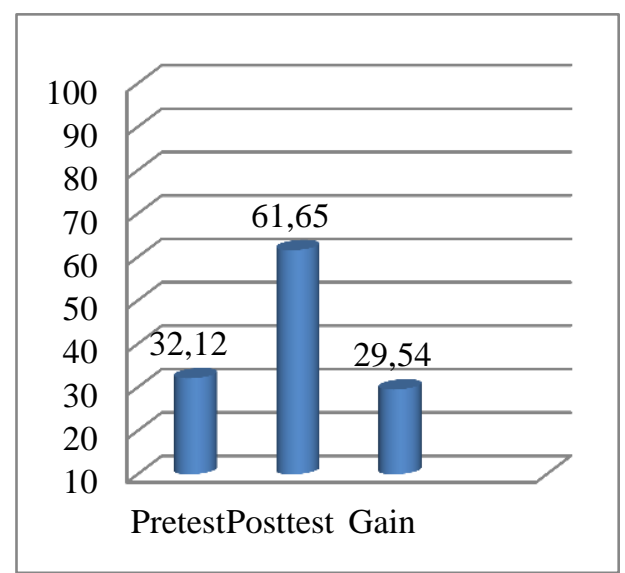

Gambar 2. hasil belajar kognitif siswa setelah penerapan model discovery learning

Persentase perbedaan hasil belajar kognitif siswa setelah penerapan model discovery learning diperoleh 0.43 dengan kategori sedang. Perbandingan nilai rata-rata hasil pretest, posttest dan $N$-gain hassil belajar kognitif siswa stelah penerapan model discovery learning mengalami peningkatan rata-rata $\mathrm{N}$-gain sebesar 0,43 dengan kategori sedang. Hasil belajar siswa sebelum penerapan model discovery learning hasil belajar kognitif siswa $100 \%$ tidak tuntas. Setelah diterapkan model discovery learning hasil belajar kognitif siswa meningkat sebanyak $63,64 \%$ dinyatakan 


\section{JPSP: Jurnal Penelitian Sains dan Pendidikan}

\section{https://e-journal.iain-palangkaraya.ac.id/index.php/mipa/}

tuntas, dan yang tidak tuntas sebesar $36,36 \%$.

Hal yang mempengaruhi masih banyaknya siswa yang belum tuntas adalah kurang aktifnya sebagian siswa keika proses pembelajaran berlangsung, baik ketika berdiskusi kelompok maupun secara mandiri untuk mecoba menemukan konsep. Selain itu juga kurangnya dalam pengelolaan waktu serta jumlah siswa yang terlalu banyak dalam kelas. Sehingga menyebabkan ruang kelas sebagai lingkungan proses pembelajaran berlangsung kurang kondusif.

Terdapat perbedaan hasil belajar kognif siswa sebelum dan setelah penerapan model discovery learning yang ditunjukan pada grafik 3. Kendala-kendala dapat diatasi dengan cara menciptakan suasana yang kondusif dan menekankan siswa untuk berperan aktif dalam berdiskusi guna meningkatkan penemuan, pemahaman konsep dan pemecahan masalah yang dihadapi. Pada hakikatnya model discovery ini menuntut siswa sebagai aktor utama dalam proses pembelajaran sedangkan guru hanya sebagai fasilitator, hanya membimbing mengarahkan kegiatan belajar siswa sesuai dengan tujuan Sardiman (2005). Selain itu penelitian sebelumnya yang dilakukan oleh Putri dkk (2017) menyatakan bahwa dengan diterapkannya model discovery learning berpengaruh signifikan terhadap hasil belajar siswa dalam pembelajaran fisika di MAN Bondowoso, model discovery learning sangat menarik dan membuat materi pembelajaran lebih mudah dipahami, sehingga hasil belajar siswa meningkat.
Berdasarkan hasil dan pembahasan dapat disimpulkan bahwa terdapat perbedaan yang signifikan motivasi dan hasil belajar siswa MTs Muslimat NU Palangka Raya sebelum dan sesudah penerapan model pembelajaran discovery learning pada materi besaran dan satuan dengan tingkat ketuntasan sebesar 63,64\% dalam kategori sedang.

\section{DAFTAR PUSTAKA}

Arikunto, Suharsimi. 2006. Prosedur Penelitian Suatu Pendekatan Praktek. Jakarta: Rineka Cipta.

Brumer, Jerome S. 1999. The Process of Education. London: Harvard University Press. Dalam Dahar, Ratna Wilis. (2011). Teori -Teori Belajar dan Pembelajaran. Jakarta: Erlangga.

Dahar R. 2006. Teori-Teori Belajar \& Pembelajaran. Jakarta : Erlangga

Hadiono, Hidayati NA. 2016. Penerapan Model Pembelajaran Discovery Learning Untuk Meningkatkan Motivasi Dan Hasil Belajar Siswa Kelas VIII-D SMPN 2 Kamal Materi Cahaya. Jurnal Pena Sains, 3(2), 77-84.

Putri RH, Lesmono AD, Aristya PD. 2017. Pengaruh Model Discovery Learning Terhadap Motivasi Belajar Dan Hasil Belajar Fisika Siswa Man Bondowoso. Jurnal Pembelajaran Fisika, 6(2), 173180 .

Hamalik O. 2006. Proses Belajar Mengajar, Bandung: Bumi Aksara

Roestiyah. 2008. Strategi Belajar Mengajar. Jakarta: Rineka Cipta 
JPSP: Jurnal Penelitian Sains dan Pendidikan

https://e-journal.iain-palangkaraya.ac.id/index.php/mipa/

Sardiman. 2005. Interaksi dan Motivasi

Belajar Mengajar. Jakarta: Raja

Grafindo Persada 